\title{
RUSLE and GIS-based assessment of soil erosion in the mountain areas of Beijing, China
}

\author{
Weiwei Zhang ${ }^{1, a}$, Hong $\mathrm{Li}^{1, \mathrm{~b} \text { * }}$ \\ ${ }^{1}$ Institute of Agricultural Integrated Development, Beijing Academy of Agriculture and Forest \\ Science, 100097, China \\ azhangwei492@163.com, blihsdf@sina.com
}

Keywords: soil erosion, universal soil loss equation, geographic information system, remote sensing, Beijing

Abstract. Quantitative research on the soil erosion intensity in the mountain areas of Beijing was estimated via utilizing RUSLE model supported by GIS and RS technology. It is concluded that no erosion and slight erosion were the primary erosion intensities in the mountain areas of Beijing. The soil erosion was distributed mainly on the steep slope or risk slope of Beijing mountain areas with a gradient of greater than 15 degree, in the forest land of Beijing mountain areas and mountain areas with vegetation coverage of less than $30 \%$ or between 45 and $65 \%$.

\section{Introduction}

The northern and the western mountain areas are the green ecological protective screen and the main water conservation area of Beijing, China, and are of great importance for its ecological environment and sustainable development. However, soil erosion has occurred in some mountain areas due to the influence of various factors, which severely destroyed the local ecological environment and become one of the key restriction factors affecting the ecological environment of Beijing. Thus, soil erosion assessment is of great reference value and guiding function for soil and water conservation, non-point source pollution evaluation and the ecological function zoning of the studied areas.

In practice, the studies on soil erosion are mostly based on soil loss equation, namely Universal Soil Loss Equation (USLE) and the Revised Universal Soil Loss equation (RUSLE). There two equations can give the sensitivity level of soil erosion by using assessment indicator system. In recent years, many scholars evaluate soil erosion and its spatial distribution by integrating USEL/RUSLE with geographic information system (GIS). On the basis of the data of climate, soil, topography and land utilization of the mountain areas of Beijing, this paper evaluated and determined the soil erosion status and distributions of the study areas, which aimed to provide theoretical basis and guidance for soil-water protection and ecological function zoning of the mountain areas of Beijing.

\section{Materials and Methods}

\section{RUSLE Soil Erosion Model}

RUSLE and USLE can be expressed as:

$$
\mathrm{A}=\mathrm{R} * \mathrm{~K} * \mathrm{~L} * \mathrm{~S} * \mathrm{C} * \mathrm{P}
$$

Where $\mathrm{A}=$ the estimation of soil loss amount $\left(\mathrm{Mg} \mathrm{km}^{-2}\right.$ per year)

$\mathrm{R}=$ rainfall-runoff erosivity factor $\left(\left(\mathrm{MJ} \mathrm{mm} \mathrm{km} \mathrm{m}^{-2}\right.\right.$ per year $)$

$\mathrm{K}=$ soil erodibility factor $\left(\mathrm{Mg} \mathrm{h} \mathrm{MJ} \mathrm{mm}^{-1}\right)$

$\mathrm{L}=$ the slope length factor $(\mathrm{m})$

$\mathrm{S}=$ the slope steepness factor $(\%)$

$\mathrm{C}=$ the cover-management practice factor

$\mathrm{P}=$ the support practice factor

Rainfall-runoff Erosivity Factor (R). Rainfall erosivity factor, R-factor, reflects the potential erosive capability of rainfall on soil, is related with precipitation amount and intensity, duration, raindrop size and velocity. However, rainfall erosivity is unavailable or very difficult to be determined 
directly. Nevertheless, many simple algorithms are proposed to calculate $\mathrm{R}$ value, for example, average annual precipitation, average monthly precipitation, annual precipitation, monthly precipitation and daily precipitation are employed in the calculation of R-factor. In the study of the rainfall erosivity of Beijing, the daily precipitation data of different years obtained from the meteorological stations was used to establish the relationship between the multi-year average rainfall erosivity and the average annual precipitation, average monthly precipitation or monthly precipitation [1], and monthly precipitation was proved to be the best method to calculate the multi-year average rainfall erosivity.

$$
\begin{aligned}
& R=5.2562 F_{F}^{1.3057} \\
& F_{F}=\frac{1}{N} \sum_{i=1}^{N}\left(\sum_{j=1}^{12} P_{i, j}^{2}\right) /\left(\sum_{j=1}^{12} P_{i, j}\right)
\end{aligned}
$$

Soil Erodibility Factor (K). Soil erodibility factor, K-factor, reflects the soil sensitivity to erosion, and it is affected by soil structure, organic content and soil profile permeability, in particular, it is highly correlated with soil mechanical composition and organic content. Considering that it is not easy to determine the necessary parameters to calculate K-factor in RUSLE equation, many scholars suggested some easy methods which can provide a reference for the calculation of K-factor in the area researches. For example, Williams et al. (1990) suggested a simple computing method in erosion/productivity evaluation model ERIC, namely K-factor was calculated by building relationships with the contents of soil sand, silt, clay and soil organic carbon [2]. The formula is expressed as Eq. 3.

$$
\begin{aligned}
& K=\{0.2+0.3 \exp [-0.0256 \operatorname{SAN}(1-S I L / 100)]\} \cdot\left(\frac{S I L}{S I A+S I L}\right)^{0.3} \cdot \\
& {\left[1.0-\frac{0.25 C}{C+\exp (3.72-2.95 C)}\right] \cdot\left[1.0-\frac{0.7 S N_{1}}{S N_{1}+\exp \left(-5.51+22.9 S N_{1}\right)}\right]}
\end{aligned}
$$

Where $S A N$ is sand content $\%$, SIL is silt content $\%, S I A$ is clay content $\%, C$ is organic carbon content $\%, S N_{1}=1-S A N / 100$.

In this paper, the study was based on the soil data including the mechanical structure and the organic content of the existing soil samples, the K-factor of each soil sample in the mountainous watershed of Beijing was calculated with the above formula. Then, the spatial distribution map of K-factor was generated using Kriging interpolation from geostatistical analysis method.

Slope Length Factor (L). Slope length factor, L-factor, denotes the ratio of soil loss amount on a certain slope to that on a typical slope of standard runoff plots under the same conditions. L-factor can be evaluated with the empirical formula developed by Wischmeier and Smith [3]:

$$
L=\left(\frac{l}{22.13}\right)^{m}
$$

Where $L$ is the slope length factor, $l$ is the slope length (m), $m$ is slope length index. When $\theta<1 \%$, $m=0.2 ; 1 \% \leq \theta<3 \%, m=0.3 ; 3 \% \leq \theta<9 \%, m=0.4 ; \theta \geq 9 \%, m=0.5 . \theta$ is the gradient.

Slope Steepness Factor (S). Slope steepness factor, S-factor, an erosion acceleration factor, denotes the ratio of soil loss amount on a certain slope to that on a typical slope of standard runoff plots under the same conditions. It reflects the effect of topography and landform character to soil erosion by integrating with L-factor. Liu et al. (1994) suggested that the best S-factor formula was developed from McCool's study on gentle slope [4]. Furthermore, Liu et al. proposed the S-factor computational formula for steep slope. Therefore, in this paper, the formulas proposed by McCool and Liu were respectively applied in the study of gentle and steep slopes.

$$
\begin{array}{lrl}
S=10.8 \sin \theta+0.03 & \theta<5^{\circ} \\
S=16.8 \sin \theta-0.5 & 5^{\circ} \leq \theta<10^{\circ}
\end{array}
$$




$$
S=21.91 \sin \theta-0.96 \quad \theta \geq 10^{\circ}
$$

Where $S$ is the slope factor, $\theta$ is the gradient.

Cover Management Practice Factor (C). Cover-management practice factor, C-factor, reflects the combined action of vegetation cover and management on soil erosion, varying between the ranges of 0-1. Its value depends on the combined action of specific vegetation cover, rotation sequence and management measure [5]. In this paper, the relationship between the value of C-factor and the coverage of vegetation was obtained with the mathematical model of slope sediment yield and vegetation coverage [6].

$$
C=0.6508-0.3436 \times \lg c
$$

The minimum value of $C$ is 0 , and $c$ is $78.3 \%$. When $c>78.3 \%$, the value of $C$ can be considered as 0 . The maximum value of $C$ is 1 , and the calculated value of $c$ is 0.1 . When $c<0.1 \%$, the value of $C$ can be considered as 1 . Normalized differential vegetation index (NDVI) was employed to calculate the vegetation coverage $c$ :

$$
c=(\text { NDVI-NDVImin)/(NDVImax-NDVImin) }
$$

Support Practice Factor (P). The factor of soil and water conservation measure, P-factor, refers to the ratio of soil loss amount after taking special measures to that under downslope cultivation, its value varies between 0 and 1 , in which, 0 refers to the regions without erosion, and 1 refers to the region without taking any regulatory measures. Considering that there was no regional test, in this paper, the value of P-factor was calibrated mainly according to the no. 703 manual from United States Department of Agriculture and the related literatures.

Data and Processing. The geometric correction and projection transformation for all data was performed in ArcGIS. The projection type was Albers. Before data overlapping, all data was transformed into raster data (grid) with a grid size of $30 \mathrm{~m}$.

\section{Results and Analysis}

\section{Soil Erosion Intensity and Spatial Distribution of Beijing Mountain Areas}

In terms of soil erosion intensity, no erosion and slight erosion were the primary erosion intensities in the mountain areas of Beijing. In which, no erosion accounted for 54.08\% of the total erosion intensities of the mountain areas, followed by $34.93 \%$ slight erosion. From the view of spatial distribution, slight erosion was intensively distributed in all the counties. However, the moderate and severer erosions were mainly distributed in the river banks, especially in the transitional gully region of river terrace and floodplain.

Table 1. Soil erosion intensity of Beijing mountain areas

\begin{tabular}{|c|c|c|c|}
\hline Erosion intensity & $\begin{array}{c}\text { Erosion modulus } \\
\left(\mathrm{t} / \mathrm{km}^{2} / \mathrm{a}\right)\end{array}$ & Area $\left(\mathrm{km}^{2}\right)$ & $\begin{array}{c}\text { Proportio } \\
\mathrm{n}\end{array}$ \\
\hline No erosion & $<200$ & 6511.08 & $54.08 \%$ \\
\hline Slight erosion & $200 \sim 2500$ & 4205.65 & 34.93 \\
\hline Moderate erosion & $2500 \sim 5000$ & 1000.60 & 8.31 \\
\hline Severe erosion & $5000 \sim 8000$ & 281.17 & 2.34 \\
\hline Extremely severe erosion & $>8000$ & 40.77 & 0.34 \\
\hline
\end{tabular}


Soil Erosion of Different Gradients in the Mountain Areas of Beijing. Gradient is a key factor affecting soil erosion. According to table 2, the soil erosion was distributed mainly on the steep slope or risk slope of Beijing mountain areas with a gradient of greater than 15 degree. In addition, the slope with a gradient between 7 and 15 degree was also existed. Table 3 suggested that the occurrence probability of erosion was gradually increased with the increasing of gradient.

Table 2. Soil erosion area of different gradients. Unit: $\mathrm{km}^{2}$

\begin{tabular}{|c|c|c|c|c|c|c|}
\hline Erosion intensity & $\begin{array}{c}<3 \\
\text { degree }\end{array}$ & $\begin{array}{c}3-7 \\
\text { degree }\end{array}$ & $\begin{array}{c}7-15 \\
\text { degree }\end{array}$ & $\begin{array}{c}15-25 \\
\text { degree }\end{array}$ & $\begin{array}{c}25-35 \\
\text { degree }\end{array}$ & $\begin{array}{c}>35 \\
\text { degree }\end{array}$ \\
\hline No erosion & 4019.08 & 432.86 & 1017.05 & 872.60 & 161.79 & 7.70 \\
\hline Slight erosion & 15.80 & 206.48 & 1329.95 & 2026.82 & 565.40 & 61.21 \\
\hline Moderate erosion & 0.00 & 0.00 & 38.56 & 668.30 & 281.18 & 12.55 \\
\hline Severe erosion & 0.00 & 0.00 & 0.44 & 61.07 & 174.65 & 45.01 \\
\hline $\begin{array}{c}\text { Extremely } \\
\text { severe erosion }\end{array}$ & 0.00 & 0.00 & 0.00 & 3.04 & 21.91 & 15.82 \\
\hline $\begin{array}{c}\text { Erosion } \\
\text { percentage \% }\end{array}$ & $\mathbf{0 . 2 9}$ & $\mathbf{3 . 7 4}$ & $\mathbf{2 4 . 7 6}$ & $\mathbf{4 9 . 9 1}$ & $\mathbf{1 8 . 8 7}$ & $\mathbf{2 . 4 3}$ \\
\hline
\end{tabular}

Table 3. The ratio of soil erosion on different gradients. Unit:\%

\begin{tabular}{|c|c|c|c|c|c|}
\hline Gradient & No erosion & $\begin{array}{c}\text { Slight } \\
\text { erosion }\end{array}$ & $\begin{array}{c}\text { Moderate } \\
\text { erosion }\end{array}$ & $\begin{array}{c}\text { Severe } \\
\text { erosion }\end{array}$ & $\begin{array}{c}\text { Extremely } \\
\text { severe } \\
\text { erosion }\end{array}$ \\
\hline$<3$ degree & 99.61 & 0.39 & 0 & 0 & 0 \\
\hline $3-7$ degree & 67.7 & 32.3 & 0 & 0 & 0 \\
\hline $\begin{array}{c}7-15 \\
\text { degree }\end{array}$ & 42.63 & 55.74 & 1.62 & 0.02 & 0 \\
\hline $\begin{array}{c}15-25 \\
\text { degree }\end{array}$ & 24.03 & 55.81 & 18.4 & 1.68 & 0.08 \\
\hline $\begin{array}{c}25-35 \\
\text { degree }\end{array}$ & 13.43 & 46.92 & 23.34 & 14.49 & 1.82 \\
\hline $\begin{array}{c}>35 \\
\text { degree }\end{array}$ & 5.41 & 43.02 & 8.82 & 31.63 & 11.12 \\
\hline
\end{tabular}

Soil Erosion of Different Land Use in the Mountain Areas of Beijing. Soil utilization is also an important factor affecting soil erosion. Table 4 and 5 indicated that soil erosion was primarily distributed in the forest land of Beijing mountain areas. In terms of the soil erosion of different land-use types, the erosion was most likely to occur in forest land and unused land, accounting for $61.34 \%$ and $80.97 \%$ respectively, and the erosion intensity was also higher. 
Table 4. Soil erosion area of different land-use types. Unit: $\mathrm{km}^{2}$

\begin{tabular}{|c|c|c|c|c|c|}
\hline $\begin{array}{c}\text { Erosion } \\
\text { intensity }\end{array}$ & Farmland & Field & Forest land & Grassland & Unused land \\
\hline Slight erosion & 100.37 & 195.39 & 3624.05 & 10.06 & 151.42 \\
\hline $\begin{array}{c}\text { Moderate } \\
\text { erosion }\end{array}$ & 7.46 & 21.47 & 865.20 & 0.40 & 88.97 \\
\hline Severe erosion & 1.03 & 3.70 & 230.20 & 0.02 & 39.91 \\
\hline $\begin{array}{c}\text { Extremely } \\
\text { severe erosion }\end{array}$ & 0.12 & 0.37 & 33.69 & 0.00 & 4.46 \\
\hline $\begin{array}{c}\text { Erosion } \\
\text { percentage\% }\end{array}$ & $\mathbf{2 . 0 3}$ & $\mathbf{4 . 1 1}$ & $\mathbf{8 8 . 3 8}$ & $\mathbf{0 . 1 9}$ & $\mathbf{5 . 2 9}$ \\
\hline
\end{tabular}

Table 5. The occurrence ratio of soil erosion of different land-use types. Unit: \%

\begin{tabular}{|c|c|c|c|c|c|}
\hline $\begin{array}{c}\text { Land } \\
\text { utilization }\end{array}$ & No erosion & $\begin{array}{c}\text { Slight } \\
\text { erosion }\end{array}$ & $\begin{array}{c}\text { Moderate } \\
\text { erosion }\end{array}$ & $\begin{array}{c}\text { Severe } \\
\text { erosion }\end{array}$ & $\begin{array}{c}\text { Extremely } \\
\text { severe erosion }\end{array}$ \\
\hline Farmland & 92.31 & 7.08 & 0.53 & 0.07 & 0.01 \\
\hline Field & 73.02 & 23.86 & 2.62 & 0.45 & 0.04 \\
\hline Forest land & 38.66 & 46.77 & 11.16 & 2.97 & 0.43 \\
\hline Grassland & 73.76 & 25.19 & 0.99 & 0.05 & 0 \\
\hline Unused land & 19.03 & 43.05 & 25.3 & 11.35 & 1.27 \\
\hline
\end{tabular}

Soil Erosion of Different Vegetation Coverage in Beijing Mountain Areas. Table 6 suggested that soil erosion was mainly distributed in Beijing mountain areas with vegetation coverages of less than $30 \%$ or between 45 and $65 \%$, followed by the regions with vegetation coverages of greater than $65 \%$. The occurrence probability reached the minimum when the coverage was within the ranges of $30-45 \%$.

Table 6. Soil erosion areas of different vegetation coverages. Unit: $\mathrm{km}^{2}$

\begin{tabular}{|c|c|c|c|c|}
\hline Erosion intensity & $\begin{array}{c}\text { Coverage } \\
\leq 30 \%\end{array}$ & $\begin{array}{c}\text { Coverage } \\
30 \%-45 \%\end{array}$ & $\begin{array}{c}\text { Coverage } \\
45 \%-65 \%\end{array}$ & $\begin{array}{c}\text { Coverage } \\
\geq 65 \%\end{array}$ \\
\hline Slight erosion & 1494.07 & 759.71 & 1161.80 & 790.03 \\
\hline Moderate erosion & 289.77 & 163.48 & 285.54 & 261.79 \\
\hline Severe erosion & 79.12 & 41.09 & 79.11 & 81.85 \\
\hline $\begin{array}{c}\text { Extremely } \\
\text { severe erosion }\end{array}$ & 10.07 & 6.22 & 12.26 & 12.22 \\
\hline $\begin{array}{c}\text { Erosion } \\
\text { percentage\% }\end{array}$ & $\mathbf{3 3 . 8 8 \%}$ & $\mathbf{1 7 . 5 6 \%}$ & $\mathbf{2 7 . 8 3 \%}$ & $\mathbf{2 0 . 7 3 \%}$ \\
\hline
\end{tabular}

\section{Conclusions}

On the basis of the data of climate, soil, topography and land utilization of the mountain areas of Beijing, this paper evaluated and determined the soil erosion status and distributions of the study areas, and analyzed the change characteristics of soil erosion under the influence of various factors, which aimed to provide theoretical basis and guidance for soil-water protection, nonpoint source pollution evaluation and ecological function zoning of Beijing mountain areas. 


\section{Acknowledgements}

This work was financially supported by Beijing Science and Technology Programs (D131100000613002).

\section{References}

[1] Zhihan Ye, Baoyuan Liu, Wenbo Zhang, et al., Study of rainfall erosivity and its spatial distribution in Beijing, Science of Soil and Water Conservation. 1 (2003) 16-20.

[2] J.R. Williams, A.N. Sharply, EPIC-Erosion Productivity Impact Cacalator I, Model Documentation, US Department of Agriculture Technical Bulletin, 1990, 1768.

[3] W.H. Wischmeier, D. D. Smith, Predicting rainfall erosion losses, U S Department of Agriculture, Agriculture Handbook. 537 (1978) 10-34.

[4] B.Y. Liu, M.A. Nearing, L.M. Risse, Slope Gradiment Effects on Soil Loss for Slopes, Transactions of the ASAE. 37 (1994) 1835-1840.

[5] Z.J. Luo, Y.L. liu, Z.L. Jia, Study on estimation of the amount of soil erosionin small watershed based on GIS and RS, Journal of Central China Normal University(Natural Sciences). 39 (2005) 269-277.

[6] H.P. Geng, B.T. Pan, C. Wang, et al., Soil erosion of Yuzhong County based on GIS and RS, Journal of Lanzhou University(Natural Sciences). 45 (2009) 8-13. 